doi: 10.52370/TISC21484SS

\title{
"COVID PASSPORTS" - LEGAL ASPECT, POSSIBLE USE AND IMPACT ON TOURISM DEVELOPMENT
}

\author{
Sanja Škorićn ; Vladimir Jovanović $^{2}$
}

\begin{abstract}
"COVID" or immunity passports are classified as one of the reactions to the world pandemic and its suppression at the international level. Given that implications of this document, its legal nature, the manner of exercising the right to it, etc., are still not quite clear, various dilemmas may arise regarding this document. Also, how much will another bureaucratic obligation in connection with the organization of travel affect tourism, which has suffered incredible financial losses in the past year? It is very difficult to predict the direction of development of tourism and tourist services, especially not after the adoption of the basic rules that will concern "COVID" passports. There are dilemmas about this document in the legal sense, as well as in the sense of its obligation - will each state individually decide whether it is obligatory to enter in it or will it be one of the obligations of everyone at the international level?
\end{abstract}

Key Words: "COVID passports", Legal aspects of the document, Pandemic responses, Tourist development

JEL classification: $K 10, K 38, Z 32, I 18, F 62, D 72$

\section{Introduction}

Since the beginning of the pandemic, which first engulfed China at the end of 2019 , and then the rest of the world in 2020, losses were suffered by almost all industries. But the biggest losses have been suffered and still do so, the entertainment industry, tourism and catering and the air transport and industry. According to the estimates available so far, tourism in the first five

\footnotetext{
${ }^{1}$ Sanja Škorić, Assistant professor, Faculty of Law for Commerce and Judiciary in Novi Sad, Geri Karolja 1,+381638219788, sanja@pravni-fakultet.info

${ }^{2}$ Vladimir Jovanović, Full professor, Faculty of Law for Commerce and Judiciary in Novi Sad, Geri Karolja 1, +381638239612, jovanovicvld@gmail.com
} 
months of 2020 has suffered over $\$ 320$ billion lost and more than 120 jobs have been at risk (United Nation, 2020, p. 2). The number of jobs cannot be precise, since the engagement of employees in tourism was very specific and the exact number could not be determined even before the pandemic, which means that it is not possible to know exactly how many jobs have been threatened and/or lost (Škorić \& Jovanović, 2018). States, while united in action and fighting a global pandemic, still decide differently what and which measures they take. This is very visible if you look at the available data according to individual states. Why is that so? Well, the answer is very simple. If you look at the data, and whether certain states have implemented restrictive measures such as full border closures or less restrictive ones, such as a mandatory negative PCR test, it will be noted that this depends on which month of the year it is, and which state it is. As a rule, the less restrictive measures were held by those countries whose GDP depends heavily on tourism as a dominant or one of the dominant activities in a country. Previously, of course, it depended on the month of the year, or whether the tourist season was at its peak in that state or not.

Table 1: Restrictive measures in some of the countries

2020

\begin{tabular}{|c|c|c|c|c|c|c|}
\hline Country & Apr & May & Jun & Jul & Sep & Nov \\
\hline Australia & Complete & Complete & Complete & Complete & Complete & Complete \\
\hline Canada & Complete & Complete & Complete & Complete & Complete & Complete \\
\hline China & Complete & Complete & Complete & Complete & Complete & Complete \\
\hline France & Complete & Complete & Partial & Partial & Partial & Partial \\
\hline Germany & Complete & Complete & Partial & Partial & Partial & Partial \\
\hline Italy & Complete & Complete & Partial & Partial & Partial & Partial \\
\hline Korea (ROK) & Other & Other & Other & Other & Other & Other \\
\hline Russian Federation & Complete & Complete & Complete & Complete & Partial & Partial \\
\hline United Kingdom & Other & Other & Other & Other & Other & Other \\
\hline United States & Other & Other & Partial & Partial & Partial & Partial \\
\hline
\end{tabular}

Travel Restrictions

Complete border closure: Borders are completely closed to tourism

Partially closed: Borders are partially closed and/or have suspended all/some flights

Other measures: Visa issuances, quarantine or mandatory testing

Lifted for international tourism: Lifted all COVID-19 related restrictions for international tourism

Source: UNWTO (2021) 
Table 2: Restrictive measures in the World COVID - 19 RELATED TRAVEL RESTRICTIONS

- Compiete Closure • Lifted for Tourism • Other Measures s Partial Closure

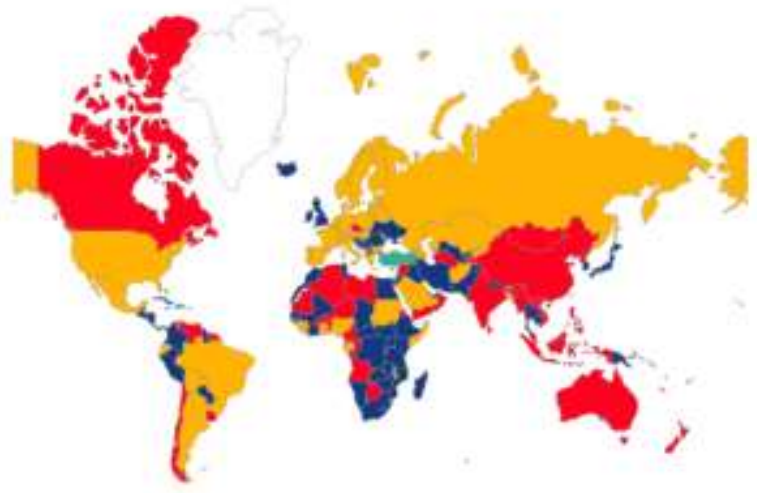

Select a manth to see rasuits for the solected month (based an the Travel Restrictions report)
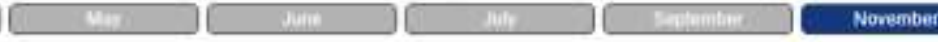

Source: UNWTO (2021)

However, since the global pandemic had unpredictable flows and development, then it is quite understandable that, for some countries, it was not crucial to loosen restrictive measures even for the sake of saving the tourist season.

Although the whole world is fighting the pandemic together, the ideas that exist in overcoming both pandemics and mitigating the catastrophic consequences it leaves behind differ from state to state, or at least, from region to region. Namely, to save the upcoming tourist season, Greece announced in January 2021 that it would be rescuing the country's tourism sector. In 2013, she proposed the idea of a "vaccination certificate" (B92, 2021). Although the idea is certainly not new, and the stated tool in jargon was referred to as a more common "COVID passport", or Immunity passport, its introduction, starting with compliance with its official name, would withdraw many doubts. The previous issue is certainly the fact that a large number of states are currently against its introduction. There is diversity in attitudes within both the EU and the Schengen area. Although there are no official statements yet on this, as the covid19 vaccination is only at the beginning. However, if the news coming to us for European Commission President Ursula von der Leyen is to be believed, the introduction of such a passport for vaccination is a "medical imperative". Sweden and Denmark share this view. The two countries thus announced 
the introduction of electronic certificates for travel abroad, which could be used to access sports or cultural events, or even restaurants in the Danish case. In Estonia, passengers are free of quarantine upon arrival if they can show proof of vaccination, PCR or serological testing. Iceland, which is not part of the EU but belongs to the Schengen area, also began issuing these digital documents at the end of January, which should facilitate movement between countries.

Although northern European countries are already ahead of the rest of the EU, they do not exclude the idea further south. Although Spain has not yet launched any vaccination passports, authorities are really in for it. "Spain is increasingly in favor of vaccination certificates and will work so that this contributes to the recovery of mobility," explained an official spokesman for Spain's Ministry of Industry, Trade and Tourism.

The same goes for Italy, where in mid-January the government's senior trustee in charge of managing the health crisis, Domenico Arcuri, said the passport was "not a bad idea" to "enable as soon as possible a return to normal activities".

For other EU countries, it is still too early to implement such a document. In France, the government does not appear to object to this idea at this stage: "Not everyone has access to the vaccine yet," Health Minister Olivier Veran said in January, who believes the debate could take "several months".

In Germany, authorities also oppose lifting restrictions only on vaccinated populations. But they don't rule out this possibility in the private sector. In Belgium, they also exclude the option that certain activities be allowed only with the possession of a vaccination passport.

In Poland, the government does not currently plan such a passport, but has launched a smartphone app called Vaccinated, which allows its owner to avoid quarantine upon entering the country.

Some EU members, such as Luxembourg, are staunchly opposed to the idea of a certificate because it would affect a person's rights. Their position is based specifically on the fact that so far there is no evidence that vaccination prevents the transmission of the virus. There is also a lack of evidence of the duration of the immunity gained by vaccines (Travel Magazine, 2021). 


\section{Possible legal nature of "COVID" passport}

Although there are no official confirmations or official addresses yet, the introduction of such documents can be considered a major certainty from this point of view. In addition to this conclusion comes the fact that the duration of the pandemic has been significantly extended, that states, even after more than a year, are retaining or re-introducing restrictive measures in the form of a complete closure. The economic aspects of these restrictive measures are very visible and cause great uncertainty, because they do not see the end or how they would end. Also, the emergence of the so-called "austerity measures" in the new strains of the virus call into question the efficacy of vaccines that began to be used in early 2021 .

Therefore, it is not a good thing to address the possible legal nature of such a document. The first ambiguities arise from the name itself. Namely, whether it will be called: Covid Passport, Immunity Passport, Certification of Immunity, etc. Although the language name may seem irrelevant to laymen, it is very important in terms of its form, but also the content, manner of enactment, conditions that must be met in order for it to be issued, expiration date, etc. Therefore, assuming that most states decide on the obligation to possess such a document as a condition of international travel, and somewhere even the conditions of performing certain activities and within national borders, its legal nature will first depend on the name adopted. If the term Passport is used in the name, then the legal nature of this document will be similar to or the same travel document, i.e. the classic passport according to the provisions of the Law on Travel Documents ("Official Gazette of RS" No. 90/2007, 116/2008, 104/2009, 76/2010, 62/2014 and 81/2019). According to the stated law, the travel identification is determined as: "The travel identification is a public identification that serves a citizen of the Republic of Serbia for crossing the state border, for travel and stay abroad, and to return to the country.

The travel identification serves to its holder to prove identity and as proof of citizenship of the Republic of Serbia" (Article 2). Further in the Law, the conditions under which it is issued, under which authority is competent to issue a passport, under what conditions it is confiscated, issue a new one, before the expiration of the applicable Etc. By strictly interpreting the specified provision, the similarity between the classic travel document, i.e. passport and so called COVID Passport, could be found in the fact that Serbian and domestic citizens have a couple on its issuance. The conditions 
they should meet in order to apply for it could, according to statements and speculations so far, be:

1. Proof of vaccination (with vaccination and revaccination date)

2. Proof of negative PCR test (with test date)

3. Proof of created antibodies (with the date of sample taking)

However, such a document would, depending on which it is issued (vaccination, negative test or positive test for antibodies) would be issued for a different period of time. Especially if we are talking about a negative PCR test that can only serve one trip, if adopted as one way of exercising the right to issue a "COVID passport". Likewise, one can rightly question who would be in charge of issuing such identification, i.e. which governing body. With no intention of entering deeper discussions about possible discrimination in this place, which will be discussed in the following text, one can write about one form of discrimination here. Namely, in the Republic of Serbia, the rules under which vaccination and revaccination are free (Euprava.gov.rs, 2021a) are valid with scheduling of appointments, and PCR testing and antibody testing are paid for (Euprava.gov.rs, 2021b).

Further looking at the similarity of the future "COVID passport" and travel documents in terms of the legal nature, is that in the Travel Documents Act the passport is treated as a public identification. Namely, the Law on General Administrative Procedure ("Official Gazette of RS" No. 18/2016 and 95/2018 - authentic interpretation), public documents are determined as: "The public identification is an identification issued by the authority within the prescribed form, within the boundaries of its jurisdiction.

(2) Public documents prove what is determined or confirmed in it. Other documents that are equal to the public identification have the same proof of value.

(3) Microfilm or electronic copy of public identification and reproduction of a copy of the public identification are equated in the process of proving with a public identification, if issued by an authority within the bounds of its jurisdiction" (Article 118).

Therefore, for public documents, the general rule is that everything in it is true, and that those who believe that there are some irregularities and inaccuracies in it must prove it.

However, it is not just a travel identification or passport that's a public identification. 
If the term Certificate, i.e. Immunity certification, is used in the name of the future document, then the legal nature of such a document will be similar to or the legal nature of the administrative act or individual act and the action of the administration without direct legal effect (Milkov,. 1997, p. 61-62). In theory, there are different classifications of individual acts and actions of management that have no immediate legal effect, and most often they are:

1. Acts of documentation

2. Acts of statement

3. Receiving statements

4. Accessor acts and

5. Administrative actions (Milkov,1997, p. 61-62).

For the subject of this work, i.e. the revelation of the possible legal nature of the future immune documentation, acts of documentation may be of importance. Acts of documentation are recording certain facts, circumstances. or conditions and issuing acts determining this. Here are two types of actions - logging actions and acts issued based on these public records.

Keeping the evidence for particular area is established by law and these records have an official character. Public administration bodies and public authority have a large number of records (Kulić, 2017, p. 116). This would mean that, for the purpose of issuing an immune document, a prescribed record must be kept as such by law. In this case, records of vaccinated and/or tested. In connection with the keeping of public records, the issuance of public documents is closely related. Namely, public administration bodies and public authority have issued public documents on facts contained in the appropriate public book (Kulić, 2012, p. 148). Competent authorities issue certificates and other documents (certificates, certificates, etc.) and the facts on which public records are kept and such documents have the importance of public documents (Kulić, 2017, p. 117).

In the eventual issuance of a future immune document, it can be viewed separately who is making records and who issues the document based on records. Namely, the records are certainly kept by the health department, the Institute of Public Health or another institution that conducts vaccinations and testing. Issuing a document based on existing records can already be a matter of controversy and should be resolved by a legal regulation that would regulate the issuance of such a document. It is assumed that this could be entrusted to local self-government or the interior 
ministry, less likely to deal with the institutions that keep such records, although this cannot be ruled out at this time either. In the very issuance process, one might also ask who is obliged to obtain the data from the records, in order to issue an immune certificate, certificate or certificate on the basis of this? Would it be the obligation of the person requiring the issuance of such a document or the authority to issue the document?

In any case, from this point of view, when there are no official confirmations yet on the introduction of such a document, it is very difficult to talk about its possible legal nature. What would be almost certain is that such a document, regardless of whether it is a passport or immunity certification or otherwise, would have the hallmarks of a public document issued on the basis of official records. However, since the conditions under which the parties would be entitled to its issuance are uncertain, then it is only right to write that the legal nature of this document will be sui generis, i.e. a mixture of more known in the domestic and international legal system.

\section{Possible consequences of the introduction of "COVID passport"}

After analyzing the possible legal nature of such a document, we come to another very sensitive topic, and these are the consequences that the issuance of such a document could arise. One of the most important is the possible discrimination that could be viewed from various aspects, from financial to direct violation of guaranteed human rights.

One type of discrimination has already been mentioned and refers to the fact that, if the issuance of this document requires proof of vaccination or a negative PCR test, given that vaccination is free and the test is paid, we have one type of discrimination.

At this point, one can also touch upon the violation of basic human rights, guaranteed by the Constitution as the highest legal act of a country. Namely, the Constitution of the Republic of Serbia ("Official Gazette of RS" No. 98/2006), proclames a general prohibition of discrimination, with a restriction if the state implements it in order to achieve full equality, where it would put all citizens in an equal position (Article 21). Further, Article 25, under the Inviolability of Physical and Mental Integrity, provides that no one may be subjected to medical or scientific experiments without his or her freely given consent. The same document also prescribes the possibility of restricting human and minority rights, but under strictly prescribed conditions (Article 20). So, when it comes to vaccination against COVID19, the only question is whether it is under medical examination or 
not, given that there are still many doubts about the virus itself, but also the effect of vaccines, the development of later immunity, etc. Further analysis of the regulations leads to the Law on Public Health ("Official Gazette of RS" No. 15/2016) and the Rulebook on Immunization and the Manner of Protection with Medicines adopted on the basis thereof ("Official Gazette of RS" No. 88/2017, 11/2018, 14/2018, 48/2018, 58/2018, 104/2018 and $6 / 2021$ ), where regular and extraordinary immunization is prescribed, which as such can be mandatory or recommended, based on the act of the Ministry of Health, and according to the recommendations of the World health organizations, at the proposal of the Institute of Public Health with the consent of the Republic Expert Commission on Infectious Diseases (Article 7). The following text of the Ordinance states that immunization is not carried out if there are contraindications (permanent or temporary) (Article 8-12). After all the above, the following conclusion can be reached which may lead to discrimination in the case of the introduction of the "COVID passport". Namely, if a person has contraindications due to which he cannot be immunized, he will not automatically fulfill the condition for issuing such a document. If, on the other hand, person decides to take a negative PCR test or serological test (assuming that the right to issue such a document can be exercised on that basis as well), we return to the story from the beginning - financial discrimination or payment for PCR and serological test. Although, the legal question is whether the Rulebook on immunization and protection of medicines is gradually harmonized first with the Law on Public Health, as a legal act of stronger legal force, and both legal acts with the Constitution, as a legal act of the highest legal force and basic principles. stated in it, due to the limited topic and scope of this paper, such an analysis could not be adequately conducted.

There are very similar conclusions in the European Union. If we analyze the basic pillars on which the European Union rests - the free movement of people, services and capital (Treaty establishing the European Community - preamble/*codified -version Official Journal C 224, 31/08/1992 P. 0001 - 0079, Maastricht) (Articles 48-53), where the introduction of an additional document that would limit the established rights and basic pillars of the EU could constitute discrimination in the form of human rights violations. Due to significant differences in the treatment of vaccination and immunization of the population against infectious diseases in EU member states, in April 2018, the European Commission adopted a Proposal - Recommendations on enhanced cooperation in the fight against diseases that can be prevented by vaccination (European Commission, 2018). 
the reduction of vaccination and confidence in the effectiveness of vaccines, the emergence and strengthening of active vaccination movements and the spread of misinformation on social networks. In a situation where there are several types of vaccines against COVID19 on the market, which have not been fully tested or their effects can not still be predicted with certainty, then it is quite certain that fears from 2018 continue today, when vaccination against COVID19. Even if it is mentioned that certain countries do not recognize vaccines of certain manufacturers, which are available to citizens, for example in Serbia, then again it can be considered that there will be discrimination in this part if the adoption of COVID Passport, obtained on the basis of immunization with a certain vaccine, which is not recognized, for example, by the state to which the document is intended to go.

On February 5, the World Health Organization issued a recommendation regarding international travel, which includes a document proving the status of vaccination or how it is stated on their official website: "The World Health Organization (WHO) issues regularly updated position papers on vaccines against diseases that have an international public health impact. This paper, which presents WHO's position on the advisability of requirements for COVID-19 vaccination or proof of vaccination for international travelers, is designed for use mainly by national public health officials and managers of immunization programs. It may also be of interest to other branches of government responsible for travel or immigration, international funding agencies, vaccine advisory groups, the medical community, the scientific media and the public.

The paper presents scientific, ethical, legal and technological considerations regarding the possible introduction of requirements by States Parties of proof of COVID-19 vaccination for outgoing or incoming international travelers, pursuant to provisions of the International Health Regulations (2005) (IHR).

It does not address the use of certificates for signifying a person's immune status, which reflects whether a person has developed antibodies in response to SARS-CoV-2 infection; whereas vaccination status reflects only whether someone has received a COVID-19 vaccine. WHO has outlined considerations regarding "immunity" passports elsewhere. In addition, for more a detailed discussion on ethical issues and considerations pertaining to immunity passports, please refer to the peer-reviewed article (WHO 2021). 
However, in addition to the following, the recommendation states that the current possession of such a document cannot be a condition for international travel, due to still critical unknowns regarding the efficacy of vaccination in reducing transmission. In addition, considering that there is limited availability of vaccines, preferential vaccination of travelers could result in inadequate supplies of vaccines for priority populations considered at high risk of severe COVID-19 disease. WHO also recommends that people who are vaccinated should not be exempt from complying with other travel risk-reduction measures.

Also, at the global level, ethical dilemmas are taken into account regarding the general state of health, viruses, testing, vaccination, etc., as well as human rights, and it is concluded that such a document, no matter how much it is currently needed, must never be part of a major strategy to combat the negative effects of the COVID19 pandemic (Teck Chuan Voo et al, 2021, p. 158-159).

\section{Introduction of "COVID passport" rules and possible impact on tourism}

Tourism, as one of the industries that has suffered the most damage from the COVID19 virus pandemic, could suffer its recovery or even greater ruin by introducing a COVID passport. It would certainly depend on the rules that would apply to the issuance of such a document, its availability, the bureaucratic complexity of the decision, the deadline in which it would have to be issued, the expiration date, but also the state in which the tourist would like to travel with a passport issued in his home state. However, if "COVID passport" were issued only for the purposes of international travel, not for the purpose of domestic tourism, what is certain is the boom in domestic tourism. Namely, even in the situation of pandemics, when restrictive measures were in effect in most countries, domestic tourists traded their plans for foreign tourist trips for domestic famous destinations (Daljine.rs, 2020). If the already complicated procedures of going to foreign tourist destinations were to be added to the obligation to issue a "COVID passport", then the so-called "COVID passport" would cause an even greater overcrowding of domestic destinations.

If we look back on the lack of rural tourism development in Serbia so far, this, although difficult situation in the world and in our country, could actually be a chance to develop this area. 
Rural tourism could be observed from several aspects, which to some extent affect it. These aspects usually have economical, ecological, cultural or institutional nature. Indicated importance of rural development, with all its possible benefits (in economic terms) for the local population, region and country, cannot be at the expense of sustainable development (Škorić \& Jovanović, 2017, p. 416).

The rich natural, cultural and historical diversity of the Republic of Serbia creates exceptional conditions for the development of rural tourism, as well as the placement of the wide offer for different segments of demand in the tourist market. Rural tourism has a large potential, because this segment of offer provides significant opportunities. The rural area, which makes up more than $85 \%$ of the territory of the Republic of Serbia, has about $43 \%$ of the population in about $42 \%$ of households that are directly or indirectly related to agriculture. Considering the natural and cultural diversity of the region, rich resource base of tourist attractions, preserved surroundings and thousands of agricultural households, the Republic of Serbia has all the conditions for the development of rural, and other special forms of tourism related to the rural area (Škorić \& Jovanović, 2017, p. 419-420). Although everything previously, only a year ago, was considered attractive to foreign tourists, with the starting of pandemics and restrictive measures, these characteristics are equal to domestic tourists from urban areas.

If the previous one adds the possibility of further development through various forms of state aid associated with the pandemic (Škorić, 2010, p. 50), then it can certainly be argued that this is now a great opportunity for domestic, especially rural tourism in Serbia.

Cohesion between globalization processes, emerging technologies and increasing competitiveness through lowering prices of tourism services is the basis for the emergence of new tourist destinations in developing regions and a new chance for international tourism (Vujović et al, 2012, p. 43). In this context, tourism is a mechanism for stimulating the economic development of certain regions where tourism potentials exist or can be created. Bearing in mind that in the Republic of Serbia, industry and other commercial sectors are not equally developed in all parts of the country, it is clear that tourism should be used as a basic instrument for achieving the prosperity of different regions (Jovanović, 2020, p. 198).

The legal framework of the Republic of Serbia in the field of tourism is the basis for the development of tourism and related industries. According to 
the Tourism Development Strategy of the Republic of Serbia for the period from 2016 to 2025, the weaknesses of the tourism in the Republic of Serbia arise from the incoordination and inactive role of local authorities, which affects competitiveness in this field (Jovanović, 2020, p. 198).

However, all issued strategies before 2020 could not have predicted the situation caused by a worldwide pandemic and that such a situation would be perhaps one of the greatest opportunities for domestic tourism development in a dozen years.

\section{Conclusion}

Based on previous analysis, first the current situation in the conditions of the worldwide pandemic, and then the possible legal nature of "COVID passport" or Immunity certification, etc., the only possible conclusion is that the introduction of such a document at the international level will be very difficult, if not impossible. Why?

First and foremost is the unpredictability of the course of the pandemic, the immunization of the population and the possible emergence of new strains of the virus due to its mutation.

Second, it is certainly a question of discrimination that would inevitably be raised by its introduction, and a very large number of bureaucratic issues that would be raised if it still opted for its introduction (application, conditions for issuance, competent issuance authorities, expiration dates, etc.)

Third, but no less important, is the issue of protecting human rights, namely, their violation, because the introduction of this document, with the condition of mandatory immunization in order to achieve the right to its issuance, could raise the question of whether it violates the basic human rights guaranteed by the constitution of the state, as the highest legal act.

No simpler situation is in the territory of the European Union, which rests on human rights and freedoms, which in particular involve the free movement of persons on the territory of the entire European Union. The introduction of a document that could jeopardize that basic pillar on which the European Union's legal system rests could jeopardize the EU itself. Here, it would only be possible to introduce a single document, recognized throughout the EU territory. However, the latest scenario is just as 
unrealistic, because there is certainly a very big difference in regulation in member states in this area. Likewise, the opinions of member states are different given the ways in which they combat the pandemics, prescribing restrictive measures, etc.

Although the COVID pandemic has left very severe consequences on tourism, as an industry, and it is still uncertain how long this effect will last even when and whether it will return to pre-pandemic levels, some areas of tourism may have their chance in such a difficult situation. This would be especially true for domestic tourism, i.e. tourism within national borders or possibly cross-border tourism with neighboring countries with which there is an agreement on not introducing restrictive measures (Bosnia and Herzegovina, for example).

\section{References}

1. B92 (2021). Da li je predlog Grčke, koji je podelio celu EU, jedini spas za turizam? [=Is Greece's proposal, which divided the entire EU, the only salvation for tourism? - 92travels.]. https://www.b92.net/putovanja/ vesti.php?nav_id=1814372 (15 February 2021).

2. Constitution of the Republic of Serbia ("Official Gazette of RS" No. 98/2006).

3. Daljine.rs (2020). Domaći turizam u nekim državama doživljava prenatrpanost [=Domestic tourism in some countries is experiencing overcrowding.]. https://daljine.rs/zbog-pandemije-domaci-turizam-unekim-drzavama-dozivljava-prenatrpanost/ (16 February 2021).

4. Euprava.gov.rs (2021a). Expression of interest in vaccination against COVID-19. https://euprava.gov.rs/usluge/6224 (15 February 2021).

5. Euprava.gov.rs (2021b). eSchedule for PCR testing. https://euprava. gov.rs/usluge/6096? (15 February 2021).

6. European Commission (2018). Proposal - Recommendations on enhanced cooperation in the fight against diseases that can be prevented by vaccination. https://eur-lex.europa.eu/legal-content/HR/TXT/PDF/? uri=CELEX:52018DC0244\&from=HR (16 February 2021). 
7. Jovanović, V. (2020). Model of toursm management in AP Vojvodina and its impact on regional development", the $5^{\text {th }}$ International Scientific Conference, Tourism in function of development of the Republic of Serbia, Tourism and Rural Development, 197-212.

8. Kulić, M. (2012). Upravno pravo [=Administrative Law], Faculty of Law for Commerce and Judiciary in Novi Sad, Novi Sad.

9. Kulić, M. (2017). Upravno pravo - opšti deo [=Administrative Lawgeneral part], Faculty of Law for Commerce and Judiciary in Novi Sad, Novi Sad.

10. Law on General Administrative Procedure ("Official Gazette of RS" No. 18/2016 and 95/2018 - authentic interpretation).

\section{Law on Public Health ("Official Gazette of RS" No. 15/2016).}

12. Law on Travel Documents ("Official Gazette of RS" No. 90/2007, 116/2008, 104/2009, 76/2010, 62/2014 and 81/2019).

13. Milkov, D. (1997). Upravno pravo II upravna delatnost, [=Administrative Law II administrative activity], University of Novi Sad Faculty of Law, Novi Sad.

14. Regulation on immunization and the way of protection of medicines ("Official Gazette of RS" No. 88/2017, 11/2018, 14/2018, 48/2018, 58/2018, 104/2018 and 6/2021).

15. Škorić, S. (2010). Tržišna dominacija i njena zloupotreba, [=Market dominance and its abuse], Andrejevic Endowment, Belgrade.

16. Škorić, S., Jovanović, V. (2017). Impact of State Aid and Legislation on Development of rural Tourism. in: Thematic Proceedings "Tourism in Function of Development of the Republic of Serbia". Faculty of Hotel Management and Tourism in Vrnjačka Banja, 411-428.

17. Škorić, S., Jovanović, V. (2018). Trends in engagement of workers in tourism - registered and survey employment. in: Thematic Proceedings "Tourism in Function of Development of the Republic of Serbia" Faculty of Hotel Management and Tourism in Vrnjačka Banja, 603-321. 
18. Teck Chuan Voo, T, Reis, A., Thomé, B., Ho, C,Tam, C., Kelly-Cirino, C., Emanuel, E. Beca, J., Littler, K., Smith, M., Parker, M, Kass, N., Ruipeng, G., Ross, L., Hursto, S. \& Munsaka, S. (2021). Immunity certification for COVID-19: ethical considerations, Policy and practice, Bull World Health Organ 99, pp. 155-161 - Bulletin of the World Health Organization (who.int) (16 February 2021).

19. Travel Magazine (2021). Pasoš o vakcinaciji podelio EU - tema o kojoj se intenzivno priča u Briselu [=The vaccination passport was shared by the EU - a topic that is intensively discussed in Brussels]. https://www.travel magazine.rs/vesti/pasos-o-vakcinaciji-podelio-eu-tema-o-kojoj-seintenzivno-prica-u-briselu/ (15 February 2021)

20. Treaty establishing the European Communiti - preamble/*codified version Official Journal C 224, 31/08/1992 P. 0001 - 0079, Maastricht.

21. United Nation (2020). Policy Brief: COVID-19 and Transforming Tourism. https://www.un.org/sites/un2.un.org/files/sg_policy_brief_ covid-19_tourism_august_2020.pdf (15 February 2021).

22. UNWTO (2021). www.unwto.org (15 February 2021).

23. Vujović, S., Cvijanović, D., Štetić, S. (2012). Destination concept of tourism development, Institute of Agricultural Economics, Belgrade.

24. WHO (2021). Interim position paper: considerations regarding proof of COVID-19 vaccination for international travellers. https://www.who.int/ news-room/articles-detail/interim-position-paper-considerationsregarding-proof-of-covid-19-vaccination-for-international-travellers (16 February 2021). 